\title{
Adendo com trecho do Livro das mil e uma noites e poemas de Adonis citados na entrevista
}

\author{
Trecho da $1^{a}$ noite das espantosas histórias das mil e uma noites: $\mathrm{O}$ \\ mercador e o gênio ${ }^{1}$
}

Disse Sahrāzād: Conta-se, ó rei venturoso, de parecer bem orientado, que certo mercador vivia em próspera condição, com abundantes cabedais, dadivoso, proprietário de escravos e servos, de muitas mulheres e filhos; em muitas terras ele investira, fazendo empréstimos ou contraindo dívidas. Em dada manhã, ele viajou para um desses países: montou um de seus animais, no qual pendurara um alforje com bolinhos e tâmaras que lhe serviriam como farnel, e partiu em viagem por dias e noites, e Deus já escrevera que ele chegaria bem e incólume à terra para onde rumava; resolveu ali seus negócios, ó rei venturoso, e retomou o caminho de volta para sua terra e parentes. Viajou por três dias; no quarto, como fizesse muito calor e aquele caminho inóspito e desértico ${ }^{2}$ fervesse, e tendo avistado um oásis adiante, correu até lá a fim de se refrescar em suas sombras. Dirigiu-se para o pé de uma nogueira a cujo lado havia uma fonte de água corrente e ali se sentou, antes amarrando a montaria e pegando o alforje, do qual retirou o farnel: bolinhos e um pouco de tâmaras. Pôs-se a comer as tâmaras, jogando os caroços à direita e à esquerda até que se saciou. Em seguida levantou-se, fez abluções e rezou ${ }^{3}$. Quando terminou os últimos versos da prece, antes que ele se desse conta, aproximara-se um velho gênio cujos pés estavam na terra e cuja cabeça tocava as nuvens, empunhando uma espada desembainhada. O gênio se achegou, parou diante dele e disse: "Levante-se para que eu o mate com essa

\footnotetext{
1 Livro das mil e uma noites, volume 1 - ramo sírio, traduzido do árabe por Mamede Mustafa Jarouche. São Paulo: Globo, 2005, p. 56. As demais notas no trecho aqui reproduzido são do próprio tradutor.

2 "Caminho inóspito e desértico" traduz a palavra árabe barr.

3 Embora descreva um ritual aparentemente islâmico e se valha da terminologia muçulmana, nesse ponto o texto parece referir-se a uma religião anterior ao islamismo.
} 
espada, do mesmo modo que você matou meu filho!", e deu uns gritos com ele. Ao ver o gênio e ouvir-lhe as palavras, o mercador ficou atemorizado e, invadido pelo pânico, disse: "E por qual crime vai me matar, meu senhor?". O gênio respondeu: "Pelo crime de ter matado o meu filho". O mercador perguntou: "E quem matou o seu filho?". Respondeu o gênio: "Você matou o meu filho". Perguntou o mercador: "Por Deus que eu não matei o seu filho! Quando e como isso se deu?". O gênio respondeu: "Não foi você que estava aqui sentado, e que tirou tâmaras da mochila, pondo-se a comê-las e a jogar os caroços à direita e à esquerda?" O mercador respondeu: "Sim, eu fiz isso". O gênio disse: "Foi assim que você matou o meu filho, pois, quando começou a jogar os caroços à direita e à esquerda, meu filho começara logo antes a caminhar por aqui, ${ }^{4}$ e então um caroço o atingiu e matou. Agora, me é absolutamente imperioso matar você". O mercador disse: "Não faça isso, meu senhor!". Respondeu o gênio: “É imperioso que eu o mate, assim como você matou o meu filho. A morte se paga com a morte". O mercador disse: "A Deus pertencemos e a ele retornaremos; não há poderio nem força senão em Deus altíssimo e poderoso. Se eu de fato o matei, não foi senão por equívoco de minha parte. Eu lhe peço que me perdoe". O gênio respondeu: "Por Deus que é absolutamente imperioso matá-lo, do mesmo modo que você matou meu filho", e, puxando-o, atirou-o ao chão e ergueu a espada para golpeá-lo. O mercador chorou, lamentou-se por seus familiares, esposa $^{5}$ e filhos. Enquanto a espada estava erguida, o mercador chorou até molhar as roupas e disse: "Não há poderio nem força senão em Deus altíssimo e poderoso", e recitou os seguintes versos:

"O tempo é composto de dois dias, um seguro, outro ameaçador, e a vida é composta de duas partes, uma pura, outra turva.

Pergunte a quem urdiu as idas e vindas do tempo:

será que o tempo só maltrata a quem tem importância?

Acaso não se vê que a ventania, ao formar as tempestades, não atinge senão as árvores de altas copas?

De tantas plantas verdes e secas existentes sobre a terra, somente se apedrejam aquelas que tem frutas;

4 O trecho "começara logo antes a caminhar por aqui”" traduz uma locução dialetal kāna kamā masà (talvez por *kāna kamā yamsi), que somente pode ser compreendida mediante a comparação com outros trechos nos quais seu sentido é mais explícito.

5 Ao contrário do que se possa imaginar, não existe aqui contradição: embora tivesse muitas mulheres e concubinas, o mercador, ao que parece, tinha somente uma esposa (legítima). Mas note-se que um dos manuscritos ("Gayangos 49") registra sistematicamente "esposas". 
nos céus existem incontáveis estrelas,

mas em eclipse só entram o sol e a lua.

Pois é, você pensa bem dos dias quando tudo vai bem,

e não teme as reviravoltas que o destino reserva;

nas noites você passa bem, e com elas se ilude,

mas no sossego da noite é que sucede a torpeza".

Quando o mercador encerrou o choro e os versos, o gênio disse: "Por Deus que é imperioso matá-lo, mesmo que chore sangue, assim como você matou meu filho". O mercador perguntou: "É absolutamente imperioso para você?". Respondeu o gênio: "Para mim é imperioso". E tornou a erguer a espada para golpeá-lo.

Então a aurora alcançou Sahrāzād e ela parou de falar.

\section{$\operatorname{Voz}^{6}$}

Desce

entre os remos

entre as rochas, encontra

os errantes nas jarras

das noivas, no murmúrio das ostras.

Anuncia o ressurgir das raízes,

das nossas bodas, dos portos, dos cantadores -

anuncia o ressurgir dos mares.

\section{Voz ${ }^{7}$}

Mihyar é um rosto traído por seus amantes

Mihyar é sinos que não tocam

Mihyar está nos rostos

inscrito como canção

que nos visita furtiva

6 ADONIS. Poemas. Seleção e trad. do árabe Michel Sleiman. São Paulo: Companhia das Letras, 2012, p. 71.

7 Cf. ADONIS. Ob. cit., p. 66 
nas sendas claras do exílio Mihyar é o sino dos errantes neste chão da Galileia.

\section{$O \sin ^{8}$}

A palmeira se inclinou

o dia e a noite se inclinaram

ele se aproxima, é um de nós,

mas o céu

removeu seu teto de chuva, por ele se aproximou para pender

o rosto dele sobre nós, como um sino verde.

\section{Folhas ao vento no. $8^{9}$}

Sou a casa da luz que não se acende: minha inquietude arde no monte da soberba meu amor é uma almenara verde.

\section{Região dos brotos $^{10}$}

\section{Aqui esteve Ícaro}

sombreou-se sob as folhas pálidas aspirou o fogo nos quartos verdes nos brotos dóceis

\section{e balançou}

balançou o tronco e refugiou-se

enrolou-se como a tenda e depois inebriou-se voou

não se abrasou - não volte ainda Ícaro.

\footnotetext{
8 Cf. ADONIS. Ob. cit., p. 76.

9 Cf. ADONIS. Ob. cit., p. 56.

10 Cf. ADONIS. Ob. cit., p. 99
} 


\section{O tempo ${ }^{11}$}

Nos braços a espiga de tempo, a cabeça é uma torre de fogo:

Que sangue é esse que jorra da areia, que ocaso é este?

Chama do agora, nos ensine a dizer.

$\mathrm{Na}$ garganta os retalhos da história

e em frente os sinais das vítimas,

como é amarga a língua agora

como é estreita a porta o alfabeto.

Nos braços a espiga de tempo, a cabeça é uma torre de fogo:

...Agora o carrasco é o amigo? é o vizinho?

Disse: Quem segura o Hulago? quem bate? é o arrecadador?

Deem-lhe o tributo... Mulheres e homens de todo

tipo... imagens passam, gesticulamos

cochichamos, nossos passos puxam a linha do assassínio.

É deus que vem da morte

ou a morte é que vem de deus?

- A charada o deixou confuso

dobrou um arco de pavor

sobre os dias arqueados.

- Tenho um irmão perdido

um pai louco

meus filhos estão mortos,

a quem recorro? abraço a porta?

me queixo ao tapete?

- Está confuso, deem-lhe a cura,

tragam rapés de alfaqui.

Cadáveres, maravilha dos assassinos, silos de ossos.

O montinho é cabeça de criança ou pedaço de carvão?

Isto é um corpo ou esqueleto de barro?

Me inclino, remexo nos olhos, remendo a cintura

talvez me ajude imaginar

11 Cf. ADONIS. Ob. cit., p. 163. 
talvez me oriente a luz da memória

mas não adianta submeter linha fina

não adianta juntar cabeça braço perna, não dá

para saber a identidade do morto.

- Para quem a formiga ensina?

Por que o assombro? A poesia

é essa mistura do olho com a trágica fagulha

êxtase é você ver sua casa erguida a Deus em estilhaços.

A coruja de um adivinho

grita do alto do minarete

a voz dela tece um arco-íris

e chora estrangulada

até ficar alegre.

Nos braços a espiga de tempo, a cabeça é uma torre de fogo. 